\title{
Increasing plant longevity and associated metabolic events in potted carnation (Dianthus caryophyllus L. Clove Pink)
}

\author{
Mahnaz Karimi', Moazzam Hassanpour Asil1*, Hedayat Zakizadeh¹ \\ 'Department of Horticultural Sciences, Faculty of Agricultural Sciences, University of Guilan, Rasht, Iran. \\ *Corresponding author: m.hassanpourasil.h@gmail.com; hassanpurm@guilan.ac.ir \\ Received: 16 August 2012; Accepted: 22 January 2013
}

\begin{abstract}
The effects of aminooxyacetic acid, benzyladenine, and 1-methylcyclopropene treatments on the post-production flower quality of potted carnation plants (Dianthus caryophyllus L. Clove Pink) were investigated considering ethylene production and antioxidant metabolism. Maximum plant longevity (17 days) was obtained using 70 ppb of 1-methylcyclopropene. As compared to control plants, ethylene production was significantly decreased by aminooxyacetic acid at concentrations over $100 \mathrm{mg} \mathrm{L}^{-1}$, benzyladenine at 20 or $30 \mathrm{mg} \mathrm{L}^{-1}$, and 1-methylcyclopropene at 70 and $140 \mathrm{ppb}$. A significant increase in 1-aminocyclopropane-1-carboxylic-acid concentration was observed in 1-methylcyclopropene treated plants compared with the control ones. On the other hand, decline in 1-aminocyclopropane-1-carboxylic-acid concentration was observed after using 100 or $150 \mathrm{mg} \mathrm{L}^{-1}$ of aminooxyacetic acid. Use of 1-methylcyclopropene (70 or $140 \mathrm{ppb}$ ), aminooxyacetic acid (100 or $150 \mathrm{mg} \mathrm{L}^{-1}$ ), and benzyladenine (20 or $30 \mathrm{mg} \mathrm{L}^{-1}$ ) significantly decreased $\mathrm{H}_{2} \mathrm{O}_{2}$ concentration and superoxide radical when compared with the untreated control. Significant increases in activities of superoxide dismutase, catalase, and peroxidase were noticed when plants were treated with $70 \mathrm{ppb} 1$-methylcyclopropene. In conclusion, aminooxyacetic acid, benzyladenine (at high concentrations), and 1-methylcyclopropene treatments can be suitable candidates for extending plant longevity, maintaining the visual quality, and reducing the loss of flower anthocyanin.
\end{abstract}

Keywords: aminooxyacetic acid, benzyladenine, ethylene production, flower, 1-methylcyclopropene.

\section{INTRODUCTION}

Carnations (Dianthus caryophyllus L.) have long been grown as a cut flower, while their presentation as a potted plant is more recent and follows the development of dwarf species (Banon et al., 2002). The quality of potted carnations is often lowered during transportation and by indoor environmental conditions. It has been shown that ethylene can reduce postharvest quality of potted plants (Reid and Wu, 1992). It is a gaseous plant hormone synthesized by the oxidation of 1-aminocyclopropane-1-carboxylic acid (ACC).
Cytokinins (such as benzyladenine, BA) have been particularly effective in delaying senescence of carnation flowers by inhibiting ethylene biosynthesis (Cook et al., 1985). Different Anthurium cultivars, dipped into $200 \mathrm{mg} \mathrm{L}^{-1} \mathrm{BA}$, presented a variable effect on vase life (Paull and Chantrachit, 2001). The efficient ethylene action inhibitor (1-MCP) competitively blocks the hormonal action of ethylene through its irreversible binding to the ethylene receptor (Sisler and Serek, 1997). The ACC content of senescing miniature rose flowers pre-treated with 1-MCP was clearly higher than in the untreated 
control (Muller et al., 2001). The aminooxyacetic acid (AOA) is also used for extending the vase life of ethylene sensitive cut flowers (Rattanawisalanona et al., 2003). It inhibited senescence and delayed flower abscission in Salvia splendens (Ferrante et al., 2006).

During senescence there is an overproduction of free radicals such as superoxide anion $\left(\mathrm{O}_{2}^{-}\right)$, hydroxyl radicals $(\mathrm{OH})$, and hydrogen peroxide $\left(\mathrm{H}_{2} \mathrm{O}_{2}\right)$, which may cause damage and cell death. Superoxide dismutase (SOD) is the only enzyme capable of scavenging $\mathrm{O}_{2}^{-}$, where as $\mathrm{H}_{2} \mathrm{O}_{2}$ it can be directly degraded by catalase (CAT) or peroxidase (POD) in the presence of a reductant (Mates, 2000; Djanaguiraman et al., 2010). The decrease in $\mathrm{O}_{2}^{-}$and $\mathrm{H}_{2} \mathrm{O}_{2}$ contents in 1-MCPsprayed plants may be due to the lower levels of ethylene production and scavenging of $\mathrm{O}_{2}{ }^{-}$and $\mathrm{H}_{2} \mathrm{O}_{2}$ by such enzymes (Larrigaudiere et al., 2004).

The present study was carried out to investigate the effect of BA, AOA, and 1-MCP on ethylene production and antioxidant metabolism in potted carnation, in order to provide basic information for future strategies with the aim of increasing post-production of plant longevity in this species.

\section{MATERIAL AND METHODS}

Plant material: Potted carnation (Dianthus caryophyllus L. Clove Pink) cuttings were received from a commercial grower in Pakdasht, Varamin, Iran. The cuttings with 60-70 mm height were placed in boxes filled with perlite. Root formation at 18 to $20^{\circ} \mathrm{C}$ took about four to five weeks. The rooted cuttings were transplanted into plastic pots $(1.5 \mathrm{~L})$ that were filled with a mixture of peat and perlite $(3: 1, v / v)$, and placed under greenhouse condition: from 20 to $25 / 10$ to $15^{\circ} \mathrm{C}$ (day/night), and 50 to $60 \%$ relative humidity. Flowering occurred after five or six months.

Treatments with benzyladenine, aminooxyacetic acid, and 1-methylcyclopropene: Pots containing uniform and healthy plants were selected at flower bud stage. Treatment with BA, AOA, and 1-MCP was done immediately after the first flower buds were almost fully opened in each pot. Plants were sprayed with solutions containing 10,20 , or $30 \mathrm{mg} \mathrm{L}^{-1}$ of BA (Sigma-Aldrich, Tehran, Iran) and 50, 100, or $150 \mathrm{mg} \mathrm{L}^{-1}$ of AOA (Sigma-Aldrich, Tehran, Iran), with a fine mist to cover all surfaces of the flowers and foliage. After such technique, the plants were held in a greenhouse overnight to allow leaves to dry. For 1-MCP treatment, the plants were placed in 60-liters-plastic containers and sealed with polyethylene bags. Water was added to the powder of EthylBloc ${ }^{\top M}$ (Rohm and Hass Philadelphia, PA, USA) to evolve 1-MCP at a concentration of 70 or $140 \mathrm{ppb}$. After application of all treatments, the plants were placed in an evaluation room where the environmental conditions were: $20 \pm 2^{\circ} \mathrm{C}$, Relative Humidity $(\mathrm{RH})>60 \%$, and 12 hours under photosynthetic photon flux density of $15 \mu \mathrm{mol} \mathrm{m} \mathrm{m}^{-2} \mathrm{~s}^{-1}$, using cool-white fluorescent lamps. Such measurements were made after opening three flowers per plant.

Evaluation of plant longevity: Flower senescence was evaluated daily and defined when at least $50 \%$ of the flowers per pot were senesced.

Measurement of ethylene production: In all treatments, flowers (one for each replication) were sealed in a $250 \mathrm{~mL}$ glass vessel for the measurement of ethylene production. After two hours, $1 \mathrm{~mL}$ of the gaseous mixture of each glass was injected in a gas chromatograph (Shimadzu Gas Chromatograph) equipped with an activated alumina column fitted in a flame ionization detector. Nitrogen was used as a carrier gas. The amount of ethylene was presented as $\mathrm{nL} \mathrm{g}^{-1} \mathrm{FW} \mathrm{h}^{-1}$.

Extraction and analysis of 1-aminocyclopropane-1carboxylic-acid: For the ACC extraction, $2 \mathrm{~g}$ of crushed, frozen petal tissue was homogenized in $4 \mathrm{~mL}$ of $5 \%$ sulfosalicylic acid solution, and centrifuged for 10 minutes at 3,090 $g_{n}$ in a pre-cooled centrifuge at $4^{\circ} \mathrm{C}$. ACC was assayed as described by Bulens et al. (2011). Briefly, $0.4 \mathrm{~mL}$ of $10 \mathrm{mM} \mathrm{HgCl}$, was added to $1.4 \mathrm{~mL}$ of the extract in a $9 \mathrm{~mL}$ vial and was immediately sealed with a serum cap. Approximately $0.2 \mathrm{~mL}$ of the $\mathrm{NaOH}-\mathrm{NaOCl}$ mixture was injected into the vial through the serum cap. The mixture was mixed for five seconds and allowed to react during four minutes on ice. The sample was mixed again for five seconds in order to release all ethylene content into the vial headspace. Following the second mixing, a $1 \mathrm{~mL}$ gas sample was removed for ethylene determination by gas chromatography.

Antioxidant enzymes: POD (EC 1.11.1.7): for peroxidase assay, petals (100 mg FW) were crushed in a phosphate buffer (0.1 M, pH=7.0) containing 15\% (w/w) PVPP, 2 mM EDTA, and $0.5 \%(\mathrm{v} / \mathrm{V})$ Triton X-100. The homogenate was centrifuged at $10,000 g_{n}$ for 20 minutes and the supernatant was assayed for POD. Peroxidase activity was determined following oxidation of odianisidine in the presence of $\mathrm{H}_{2} \mathrm{O}_{2}$ at $470 \mathrm{~nm}$ (Aebi, 1983). The enzyme extract was determined according to Bradford (1976). All enzyme activities and protein concentration were quantified spectrophotometrically (6405 UV/Vis, Jenway, England).

SOD (EC 1.15.1.1): The activity was assayed as described by Beauchamp and Fridovich (1971). The reaction mixture was prepared by mixing $0.1 \mathrm{mM}$ nitroblue tetrazolium, 
$0.1 \mathrm{mM}$ EDTA, and $50 \mu \mathrm{M}$ xanthine and xanthine oxidase in $50 \mathrm{mM}$ potassium phosphate buffer $(\mathrm{pH}=7.8)$. One unit of SOD was defined as the amount of enzyme that inhibits by $50 \%$ the control rate $(0.025$ units of absorbance at $550 \mathrm{~nm} \mathrm{~min}^{-1}$ ) (McCord and Fridovich, 1969).

Catalase - CAT (EC 1. 11.1.6): The reaction mixture had $15 \mathrm{mM} \mathrm{H}_{2} \mathrm{O}_{2}$, up to $100 \mu \mathrm{L}$ of homogenate $\left(7 \mathrm{mg} \mathrm{mL}^{-1}\right.$ protein) with $0.2 \%$ (v/v) Triton $\mathrm{X}-100$ in $50 \mathrm{mM}$ potassium phosphate buffer, $\mathrm{pH}=7.0$ (Aebi 1983).

Oxidants: Hydrogen peroxide $\left(\mathrm{H}_{2} \mathrm{O}_{2}\right)$ levels in petals were measured by following the method described by Patterson et al. (1984). One $\mathrm{mL}$ of cold-acetone-extracted supernatant was added to $0.1 \mathrm{~mL} 20 \%$ titanium reagent $\left(20 \%(\mathrm{w} / \mathrm{v}) \mathrm{TiCl}_{4}\right.$ in $12.1 \mathrm{M} \mathrm{HCl}$ and $0.2 \mathrm{~mL} 17 \mathrm{M}$ ammonia solution. The solution was centrifuged at $3,000 g_{n}$ at $4^{\circ} \mathrm{C}$ for ten minutes, and the supernatant was discarded. The pellet was dissolved in $3 \mathrm{~mL}$ of $1 \mathrm{M}$ sulfuric acid. Absorbance of the solution was measured at $410 \mathrm{~nm}$ with a spectrophotometer. Absorbance values were calibrated to a standard curve generated with known concentrations of $\mathrm{H}_{2} \mathrm{O}_{2}$, which were expressed in $\mathrm{nmol} \mathrm{g} \mathrm{g}^{-1} \mathrm{FW}$.

For superoxide anion $\left(\mathrm{O}_{2}^{-}\right)$, petals were homogenized in ice cold sodium phosphate buffer $(0.2 \mathrm{M}, \mathrm{pH}=7.2)$ containing diethyl dithiocarbamate. The homogenate was immediately centrifuged for one minute at $3,000 \mathrm{~g}_{\mathrm{n}}$. In the supernatant, superoxide anion was measured by its capacity to reduce nitro blue tetrazolium $\left(2.5 \times 10^{-4} \mathrm{M}\right)$. Absorbance of the end product was measured at $540 \mathrm{~nm}$ with a spectrophotometer. Superoxide anion was expressed as a change in optical density (OD) in min $^{-1} \mathrm{~g}^{-1} \mathrm{FW}$ (Chaitanya and Naithani, 1994).

Anthocyanin determination: Petal tissues were extracted using methanol containing $1 \% \mathrm{HCL}$ for 24 hours, and the absorbance was determined by a spectrophotometer at 520 to $700 \mathrm{~nm}$ (Paliyath et al., 2008).

Statistical analysis: The experiment was carried out in a completely randomized design with four replications. Data were statistically analyzed using SAS software (Version 6.12). Mean comparisons to identify significant differences among treatments were performed using the least significant difference (LSD) at a 0.05 probability level.

\section{RESULTS}

Plant longevity: The longevity of potted plant was improved after using 1-MCP (at all concentrations), AOA (100 or $150 \mathrm{mg} \mathrm{L}^{-1}$ ), and BA (20 or $30 \mathrm{mg} \mathrm{L}^{-1}$ ). As compared to control, such variance was increased 9, 4.8, and

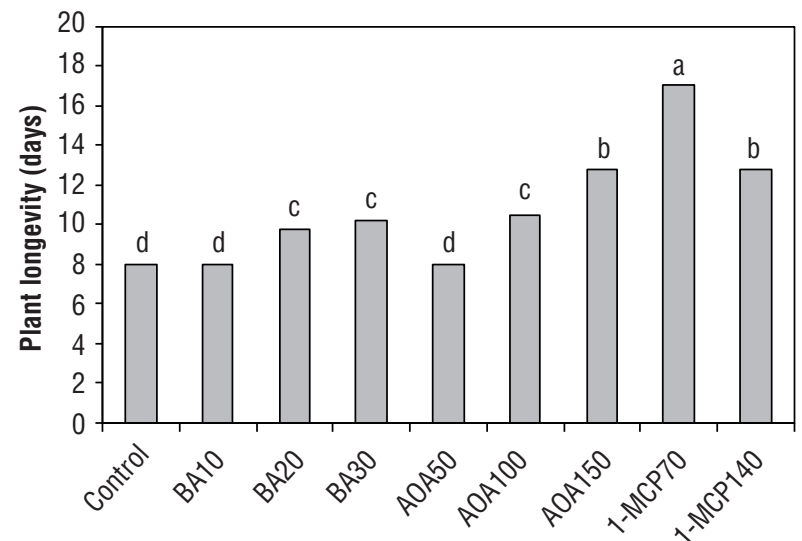

Figure 1. Plant longevity of potted carnation in response to pretreatment with different concentrations of benzyladenine (BA) at 10, 20, and $30 \mathrm{mg} \mathrm{L}^{-1}$, aminooxyacetic acid (AOA) at 50, 100, and $150 \mathrm{mg} \mathrm{L}^{-1}$, and 1-methylcyclopropene (1-MCP) at 70 and $140 \mathrm{ppb}$. Diversified letters indicate significant differences $(p<0.05)$ among means $(n=4)$.

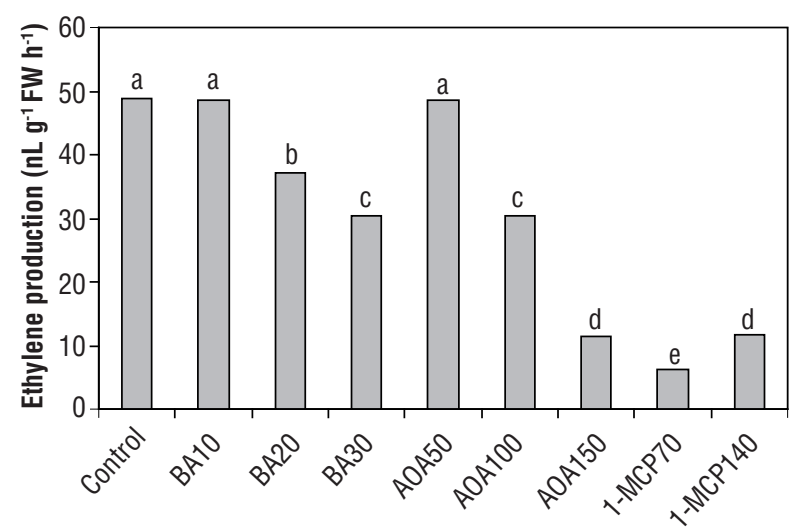

Figure 2. Flower ethylene production of potted carnation plants (on day 8 ) in response to pre-treatment with different concentrations of benzyladenine (BA) at 10,20 , and $30 \mathrm{mg} \mathrm{L}^{-1}$, aminooxyacetic acid (AOA) at 50, 100, and $150 \mathrm{mg} \mathrm{L}^{-1}$, and 1-methylcyclopropene (1-MCP) at 70 and $140 \mathrm{ppb}$. Diversified letters indicate significant differences $(p<0.05)$ among means $(n=4)$.

2.5 days by $70 \mathrm{ppb} 1-\mathrm{MCP}, 150 \mathrm{mg} \mathrm{L}^{-1} \mathrm{AOA}$, and $30 \mathrm{mg} \mathrm{L}^{-1}$ $B A$, respectively. The plants treated with $10 \mathrm{mg} \mathrm{L}^{-1} \mathrm{BA}$ and $50 \mathrm{mg} \mathrm{L}^{-1} \mathrm{AOA}$ showed the lowest plant longevity (Figure 1).

Effect of 1-methylcyclopropene, aminooxyacetic acid, and benzyladenine on ethylene production: The treatments with AOA (100 or $150 \mathrm{mg} \mathrm{L}^{-1}$ ), BA (20 or $30 \mathrm{mg} \mathrm{L}^{-1}$ ), and 1-MCP (70 or $140 \mathrm{ppb}$ ) significantly inhibited the flower ethylene production (Figure 2). Ethylene production increased sharply in the untreated flowers until the eighth day and decreased thereafter (Figure 3). Evaluation of the regression relationship between plant longevity and ethylene production showed a significant negative association between ethylene 


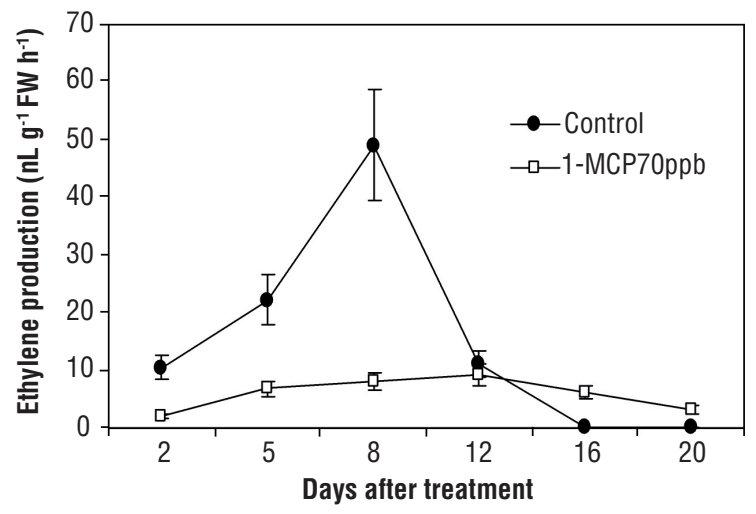

Figure 3. Flower ethylene production by control plants and ones treated with $70 \mathrm{ppb} 1-\mathrm{MCP}$, this is the best treatment for increasing longevity of potted carnation plants. Symbols are the mean values $(n=4) \pm$ standard error.

production and plant longevity, i.e., plant longevity decreases as ethylene production increases (Figure 4).

Changes in 1-aminocyclopropane-1-carboxylic-acid content of potted carnation: The effect of different treatments on ACC content of flowers was significant $(p<0.001)$. The highest one was observed with $70 \mathrm{ppb} 1-\mathrm{MCP}$. In contrast, the application of $A O A$ in high concentrations significantly decreased the ACC content in the flowers compared with 1-MCP and BA, and the untreated control (Figure 5).

Anthocyanin determination: Anthocyanin concentration of color parts in the petals increased significantly in 1-MCP (70 or $140 \mathrm{ppb}$ ), AOA (100 or $150 \mathrm{mg} \mathrm{L}^{-1}$ ), and BA (20 or $30 \mathrm{mg} \mathrm{L}^{-1}$ ) treatments (Figure 6).

Effect of 1-methylcyclopropene, aminooxyacetic acid, and benzyladenine on antoxidant metabolism: The application of 1-MCP (70 or $140 \mathrm{ppb}$ ), AOA (100 or $150 \mathrm{mg} \mathrm{L}^{-1}$ ) and $\mathrm{BA}$ (20 or $30 \mathrm{mg} \mathrm{L}^{-1}$ ) significantly decreased $\mathrm{H}_{2} \mathrm{O}_{2}$ content and superoxide radical $\left(\mathrm{O}_{2}{ }^{-}\right)$compared with the untreated control (Table 1). The lowest $\mathrm{H}_{2} \mathrm{O}_{2}$ and superoxide radical contents were obtained in the treatment with 70 ppb 1-MCP. The highest SOD, CAT, and POD activities were found in the treatment with 1-MCP. Moreover, SOD, CAT, and POD activities were significantly higher in the AOA (100 or $150 \mathrm{mg} \mathrm{L}^{-1}$ ) and $\mathrm{BA}\left(20\right.$ or $\left.30 \mathrm{mg} \mathrm{L}^{-1}\right)$ treatments if compared with the untreated plants (Table 1).

\section{DISCUSSION}

The present study clearly indicated that treatment with 1-MCP (70 or $140 \mathrm{ppb}$ ), AOA (100 or $150 \mathrm{mg} \mathrm{L}^{-1}$ ) and

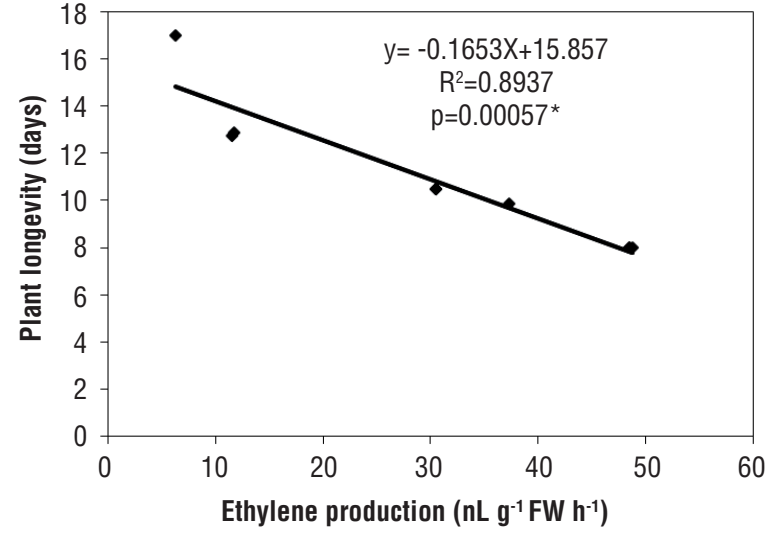

Figure 4. Relationship between ethylene production and longevity of potted carnation plants. ${ }^{*}$ Significant negative correlation.

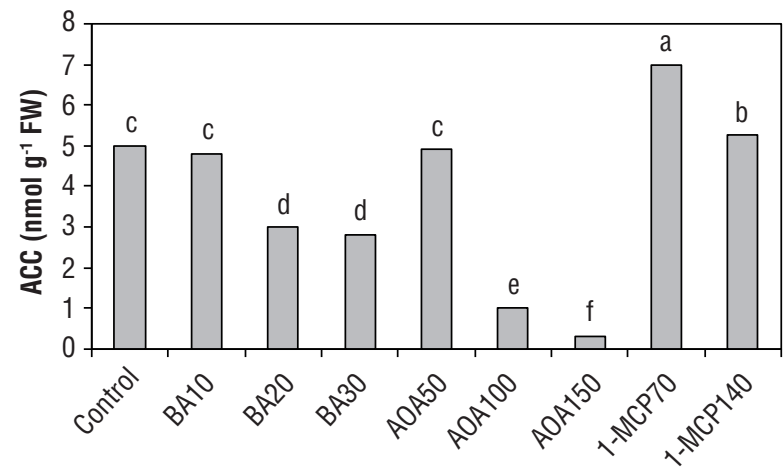

Figure 5. 1-Aminocyclopropane-1-carboxylic-acid content in petals (on day 8) as response to pre-treatment with different concentrations of benzyladenine (BA) at 10,20 , and $30 \mathrm{mg} \mathrm{L}^{-1}$, aminooxyacetic acid (AOA) at 50, 100, and $150 \mathrm{mg} \mathrm{L}^{-1}$, and 1-methylcyclopropene (1-MCP) at 70 and $140 \mathrm{ppb}$. Diversified letters indicate significant differences $(p<0.05)$ among means $(n=4)$.

$\mathrm{BA}$ (20 or $30 \mathrm{mg} \mathrm{L}^{-1}$ ) decreased ethylene production in flowers of potted carnation Clove Pink (Figure 2). They delayed the onset of wilting in the flowers, which agrees with the findings of Lerslerwong and Ketsa (2008) for Dendrobium flowers and Seglie et al. (2011) for Dianthus caryophyllus cut ones.

The success in extending the plant longevity (Figure 1) using BA could be attributed to its role in inhibiting ethylene biosynthesis. The present results are in agreement with those of Cook et al. (1985) and Han and Miller (2003). Hassanpour Asil and Karimi (2010) reported that spraying cut Lisianthus flowers with 25 or $50 \mathrm{mg} \mathrm{L}^{-1} \mathrm{BA}$ delayed ethylene production and extended its vase life. AOA is a well-known ethylene biosynthesis inhibitor and blocks the ACC synthase activity (Mensuali-Sodi et al., 2005). AOA is used for preserving 
cut flowers sensitive to ethylene (Rattanawisalanona et al., 2003). These results showed that the application of 1-MCP, an ethylene perception inhibitor, significantly decreased ethylene production rate in flowers (Figures 2 and 3). The decreased ethylene production in 1-MCP-treated 'pink' pots may have also been due to the inhibition of the autocatalytic ethylene production Pathak et al., 2003).

The increase in the ACC content of the petals coincided closely with that in the ethylene production by the flowers. The ACC content of the 'pink' plants pre-treated with 1-MCP (especially at the concentration of $70 \mathrm{ppb}$ ) was clearly higher than in control. The accumulation of ACC in 1-MCP treated flowers may indicate that the treatment reduces ACC oxidase activity and to a lesser extent ACC synthase. However, no accumulation of $A C C$ was observed after the AOA retreatment (especially at the concentration of $150 \mathrm{mg} \mathrm{L}^{-1}$ ), which suggests that ACC synthase was inhibited by AOA. Muller et al. (2001) observed that treatment with 1-MCP resulted

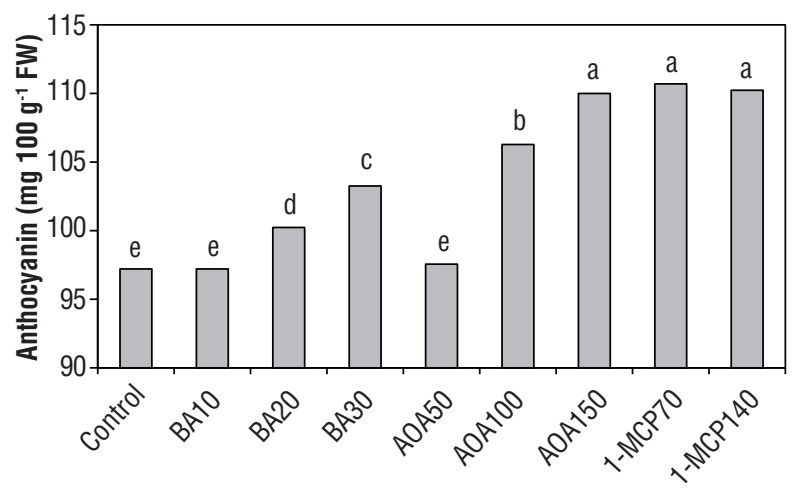

Figure 6. Anthocyanin content in petals (on day 8) as response to pre-treatment with different concentrations of benzyladenine (BA) at 10, 20, and $30 \mathrm{mg} \mathrm{L}^{-1}$, aminooxyacetic acid (AOA) at 50, 100 , and $150 \mathrm{mg} \mathrm{L}^{-1}$, and 1-methylcyclopropene (1-MCP) at 70 and $140 \mathrm{ppb}$. Diversified letters indicate significant differences $(p<0.05)$ among means $(n=4)$. in increased accumulation of ACC and reduced ethylene production during senescence in miniature rose flowers.

Plants possess a well-defined enzymatic antioxidant defense system to protect them against the reactive oxygen species (ROS), such as $\mathrm{H}_{2} \mathrm{O}_{2}, \mathrm{OH}^{-}$and $\mathrm{O}_{2}^{-}$(Mates, 2000). Larrigaudiere etal. (2004) analyzed that ethylene was involved in ROS production. During senescence, there is an overproduction of free radicals that may cause damage and consequently cell death. In our study a low level of $\mathrm{O}_{2}^{-}$and $\mathrm{H}_{2} \mathrm{O}_{2}$ was recorded in $0.5 \mathrm{mg} \mathrm{L}^{-1}$ (Table 1). The decreases in $\mathrm{O}_{2}^{-}$and $\mathrm{H}_{2} \mathrm{O}_{2}$ contents in 1-MCP sprayed plants may be due to lower levels of ethylene production and scavenging of $\mathrm{O}_{2}^{-}$and $\mathrm{H}_{2} \mathrm{O}_{2}$ by SOD and POD enzymes (Larrigaudiere et al., 2004). This study also showed that the 1-MCP-treated flowers had significantly higher SOD, CAT, and POD activities compared with the control, AOA, and BA treatments (Table 1), which is in accordance with the findings of Djanaguiraman et al. (2011) and Wang et al. (2009). Application of 1-MCP could inhibit probable loss of membrane integrity (Yuan et al., 2010), therefore lipid peroxidation could be regulated by ethylene.

Color fading and discoloration are important factors in determining visual quality of flowers and in many cases they are the main reasons for determination of post-production quality (Amarjit, 2000). The major types of pigments contributing to the color of the flowers are carotenoids and anthocyanins (Amarjit, 2000). The improvement of petal color expression is at least partially due to the increase in anthocyanin contents. Ethylene has been known to cause petal color fading. In the present study, treatments with 20 or $30 \mathrm{mg} \mathrm{L}^{-1} \mathrm{BA}, 100$ or $150 \mathrm{mg} \mathrm{L}^{-1} \mathrm{AOA}$ and 70 or $140 \mathrm{ppb} 1-\mathrm{MCP}$ reduced ethylene production in flowers. In some cases, anthocyanin degradation happens due to changes in the vacuoles that decrease the stability of the pigments and cause the chemical degradation of the anthocyanin, which results in senescence process (Hershkovits et al., 2005). Pre-treatment with 1-MCP could

Table 1. Activities of superoxide dismutase, peroxidase, catalase, and $\mathrm{H}_{2} \mathrm{O}_{2}$ and $\mathrm{O}_{2}{ }^{-}$concentrations in petals of potted carnation plants treated with benzyladenine at 10,20 , and $30 \mathrm{mg} \mathrm{L}^{-1}$, aminooxyacetic acid at 50, 100, and $150 \mathrm{mg} \mathrm{L}^{-1}$, and 1-methylcyclopropene at 70 and $140 \mathrm{ppb}$.

\begin{tabular}{|c|c|c|c|c|c|}
\hline Treatments & $\begin{array}{c}\text { SOD } \\
(\mathrm{U} \text { mg Pro-1) }\end{array}$ & 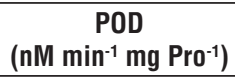 & $\begin{array}{c}\text { CAT } \\
\left(\mathrm{nM} \mathrm{min}^{-1} \mathrm{mg} \mathrm{Pro}^{-1}\right) \\
\end{array}$ & $\begin{array}{c}\mathrm{H}_{2} \mathrm{O}_{2} \\
\left(\mathrm{nmol} \mathrm{g} \mathrm{g}^{-1} \mathrm{FW}\right) \\
\end{array}$ & $\begin{array}{c}0_{2}^{-} \\
\left(\Delta \mathrm{OD} \min ^{-1} \mathrm{~g}^{-1} \mathrm{FW}\right) \\
\end{array}$ \\
\hline Control & 9.66 & 3.92 & 0.76 & 14.07 & 1.15 \\
\hline BA 10 & 9.00 & 3.85 & 0.80 & 14.05 & 1.15 \\
\hline BA 20 & 14.00 & 4.12 & 0.81 & 13.81 & 1.13 \\
\hline BA 30 & 17.00 & 11.00 & 0.89 & 13.51 & 1.08 \\
\hline AOA 50 & 10.00 & 3.06 & 0.79 & 14.07 & 1.16 \\
\hline AOA 100 & 14.00 & 6.80 & 0.89 & 13.50 & 1.08 \\
\hline AOA 150 & 20.00 & 9.38 & 0.93 & 13.21 & 1.05 \\
\hline 1-МСР 70 & 29.25 & 13.75 & 1.22 & 12.82 & 1.00 \\
\hline 1-МCP 140 & 24.00 & 11.51 & 0.96 & 13.11 & 1.04 \\
\hline LSD $(0.05)$ & 1.71 & 1.49 & 0.13 & 0.08 & 0.01 \\
\hline
\end{tabular}

SOD: superoxide dismutase; POD: peroxidase; CAT: catalase; BA: benzyadenine; AOA: aminooxyacetic acid; 1-MCP: 1-methylcyclopropene; LSD: least significant difference. 
reduce the damage of membrane in fresh product, which is an important factor involved in retaining bract discoloration (Hershkovits et al., 2005).

This study on antioxidant metabolism of potted carnation petals can be understood not only as experimental evidence confirming the hypothesis of a link between ethylene and free radicals generation in senescence, but also as a key to the development of adequate methods to prevent or delay deterioration in potted flowers.

Therefore, it could be concluded that AOA, BA (at high concentration), and 1-MCP treatments may be good candidates for extending plant longevity, maintaining the visual quality of flowers in potted carnation plants. The treatment with AOA (100 and $150 \mathrm{mg} \mathrm{L}^{-1}$ ), BA (20 or $30 \mathrm{mg} \mathrm{L}^{-1}$ ), and 1-MCP prevented the increase in the ethylene, $\mathrm{O}_{2}^{-}$, and $\mathrm{H}_{2} \mathrm{O}_{2}$ production and increased the antioxidant enzyme activity measured in petals.

\section{REFERENCES}

Aebi HE (1983) Catalase. In: Bergmeyer HU (ed), Methods of Enzymatic Analysis, Vol. 3, pp. 273-285. Verlag Chemie, Weinheim.

Amartij B (2000) Plant growth regulator in agriculture and horticulture. Part 5. Food products press 5: 147-165.

Banon S, Gonzalez A, Cano EA, Franco JA, Fernandez JA (2002) Growth, development and colour response of potted Dianthus caryophyllus cv. Mondriaan to paclobotrazol treatment. Sci. Hortic. 94:371-377.

Beauchamp CH, Fridovich I (1971) Superoxide dismutase: improved assays and an assay applicable to acrylamide gels. Anal. Biochem. 44:276-287.

Bradford MM (1976) A rapid and sensitive method for the quantitation of microgram quantities of protein utilizing the principle of protein-dye binding. Anal. Biochem. 72:248-254.

Bulens I, Van de Poel B, Hertog ML, Proft M, Geeraerd AH, Nicola BM (2011) Protocol: an updated integrated methodology for analysis of metabolites and enzyme activities of ethylene biosynthesis. Plant Methods 7:17.

Chaitanya, KSK, Naithani SC (1994) Role of superoxide, lipid peroxidation and superoxide dismutase in membrane perturbation during loss of viability in seeds of Shorea robusta Gaertn.f. New Phytol. 126:623-627.

Cook D, Rasche M, Eisinger M (1985) Regulation of ethylene biosynthesis and action in cut carnation flower senescence by cytokinins. J. Am. Soc. Hortic. Sci. 110:24-27.

Djanaguiraman M, Sheeba JA, Devi DD, Bangarusamy U, Prasad PVV (2010). Nitrophenolates spray can alter boll abscission rate in cotton through enhanced peroxidase activity and increased ascorbate and phenolics levels. J. Plant Physiol. 167:1-9.

Djanaguiraman M, Prasad PVV, Al-Khatib L (2011) Ethylene perception inhibitor 1-MCP decreases oxidative damage of leaves through enhanced antioxidant defense mechanisms in soybean plants grown under high temperature stress. Environ. Exp. Bot. 71:215-223.
Ferrante A, Mensuali-Sodi A, Serra G, Tognoni F (2006) Evaluation of post-production performance of Salvia splendens potted plants for interiors use. Acta Hortic. 723:415-419.

Han SS, Miller JA (2003) Role of ethylene in postharvest quality of cut oriental lily 'Stargazer'. Plant Growth Regul. 40:213-222.

Hassanpour Asil M, Karimi M (2010) Efficiency of benzyladenine reduced ethylene production and extending vase life of cut Eustoma flowers. Plant Omics 3:199-203.

Hershkovits V, Saguy SI, Pesis E (2005) Postharvest application of 1-MCP to improve the quality of various avocado cultivars. Postharvest Biol. Technol. 37:252-264.

Larrigaudiere C, Vilaplana R, Soria Y, Recasens I (2004) Oxidative behaviour of Blanquilla pears treated with 1-methylcyclopropene during cold storage. J. Sci. Food Agric. 84:1871-1877.

Lerslerwong L, Ketsa S (2008) Autocatalytic ethylene production by Dendrobium flowers during senescence induced by exogenous ethylene. Thai. J. Agric. Sci. 41:91-99.

Mates JM (2000) Effects of antioxidant enzymes in the molecular control of reactive oxygen species. Toxicology 153:83-104.

McCord JM, Fridovich I (1969) Superoxide dismutase. An enzymic function for erithrocuprein (hemocuprein). J. Biol. Chem. 244:6049-6055.

Mensuali-Sodi A, Ferrante A, Tognoni F, Serra G (2005) Inhibitors of ethylene action and biosynthesis on cut carnation. Agr. Med. 135:161-165

Muller R, Stummann BM, Sisler EC, Serek M (2001) Cultivar differences in regulation of ethylene production in miniature Rose flowers (Rosa hybrida L.). Gartenbauwissenschaft. 66:34-38.

Paliyath G, Murr DP, Handa AK, Lurrie S (2008) Postharvest biology and technology of fruits, vegetable and flowers. 482p. Wiley-Blackwell, Hoboken, NJ, USA.

Pathak N, Asif MH, Dhawan P, Srivastava MK, Nath P (2003) Expression and activities of ethylene biosynthesis enzymes during ripening of banana fruits and effect of 1-MCP treatment. Plant Growth Regul. 40:11-19.

Patterson BD, Macrae EA, Ferguson IB (1984) Estimation of hydrogen peroxide in plant extracts using titanium (IV). Anal. Biochem. 139:487-492.

Paull RE, Chantrachit T (2001) Benzyladenine and the vase life of tropical ornamentals. Postharvest Biol. Technol. 21:303-310.

Rattanawisalanona C, Ketsa S, van Doorn WG (2003) Effect of aminooxyacetic acid and sugars on the vase life of Dendrobium flowers. Postharvest Biol. Technol. 29:93-100.

Reid MS, Wu MJ (1992) Ethylene and flower senescence. Plant Growth Regul. 11:37-43.

Seglie L, Martina K, Devecchi M, Roggero C, Trotta F, Scariot V (2011) The effects of 1-MCP in cyclodextrin-based nanosponges to improve the vase life of Dianthus caryophyllus cut flowers. Postharvest Biol. Technol. 59:200-205

Sisler EC, Serek M (1997) Inhibitors of ethylene responses in plants at the receptor level: recent developments. Physiol. Plant. 100:577-582.

Wang B, Wang J, Feng X, Zhao Y, Jiang W (2009) Effects of 1-MCP and exogenous ethylene on fruit ripening and antioxidants in stored mango. Plant Growth Regul. 57:185-192.

Yuan G, Sun B, Yuan J, Wang Q (2010) Effect of 1-methylcyclopropene on shelf life, visual quality, antioxidant enzymes and health-promoting compounds in broccoli florets. Food Chem. 118:774-781. 